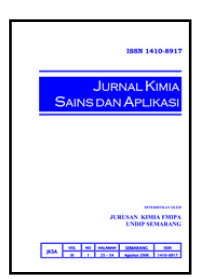

\title{
Sintesis dan Karakterisasi Silica Gel dari Tetraetilortosilikat (TEOS) Menggunakan Surfaktan Polyethylene Glycol (PEG) 6000 dalam Kondisi Basa
}

\author{
Agus Salim Purwanto ${ }^{\mathrm{a}}$, Taslimah ${ }^{\mathrm{a} *}$, Sriatun $^{\mathrm{a}}$ \\ a Inorganic Chemistry Laboratory, Chemistry Department, Faculty of Sciences and Mathematics, Diponegoro University, Jalan Prof. \\ Soedarto, Tembalang, Semarang \\ * Corresponding author: taslimah@live.undip.ac.id
}

\section{Article Info}

Keywords:

synthesis of silica gel, surfactant, polyethylene glicol (PEG) 6000, pore
Kata kunci:

sintesis silica gel, surfaktan, polyethylene glicol (PEG) 6000, pori

\begin{abstract}
Research on the synthesis of silica gel from tetraethylortosilicate (TEOS) using polyethylene glycol (PEG) 6000 surfactant under basic conditions has been conducted. This study aims were to determine the optimum $\mathrm{pH}$ of the fastest gel formation for synthesis of silica gel and determine the character of synthesized silica gel. The synthesis of silica gel was performed by mixing tetraethylortosilicate (TEOS), ethanol, aquadest, $\mathrm{NH}_{4} \mathrm{OH}$ and polyethylene glycol (PEG) 6000. In this study the $\mathrm{pH}$ was varied to $\mathrm{pH} 8-10$ and variation of PEG 6000 concentration of $0.01 \mathrm{~g} / 100 \mathrm{~mL} ; 0.03 \mathrm{~g} / 100 \mathrm{~mL}$; $0.06 \mathrm{~g} / 100 \mathrm{~mL}$. The synthesized silica gel was characterized by infrared spectrophotometer (FTIR), X-ray diffraction (XRD) and BET surface area analyzer. It was found that $\mathrm{pH} 9$ was the optimum $\mathrm{pH}$ for gel formation. The results of $\mathrm{X}$-ray diffraction analysis (XRD) showed that the silica gel was amorphous while the BET surface area analyzer displayed that the silica gel was mesopori. The highest total pore volume and specific silica gel surface area obtained at pH 9 and with PEG 6000 concentration of $03 \mathrm{~g} / 100 \mathrm{~mL}$ were $124,574 \mathrm{~cm}^{3} / \mathrm{g}$ and $285.46 \mathrm{~m}^{2} / \mathrm{g}$ respectively.
\end{abstract}

\section{Abstrak}

Penelitian tentang sintesis silika gel dari tetraetilortosilikat (TEOS) menggunakan surfaktan polyethylene glicol (PEG) 6000 dalam kondisi basa telah dilakukan. Penelitian ini bertujuan untuk menentukan pH optimum pembentukan gel tercepat untuk sintesis silica gel dan menentukan karakter silika gel hasil sintesis. Sintesis silica gel dilakukan dengan mencampurkan tetraetilortosilikat (TEOS), etanol, aquades, $\mathrm{NH}_{4} \mathrm{OH}$ dan polietilen glikol (PEG) 6000. Penelitian ini dilakukan variasi $\mathrm{pH}$ 8-10 dan variasi konsentrasi PEG 6000 yaitu 0,01 g/100 mL; 0,03 g/100 mL; 0,06 g/100 mL. Silika gel hasil sintesis dikarakterisasi dengan spektrofotometer inframerah (FTIR), difraksi sinar-X (XRD) dan BET surface area analyzer. Diperoleh bahwa $\mathrm{pH} 9$ sebagai $\mathrm{pH}$ optimum untuk pembentukan gel. Hasil analisis difraksi sinar-X (XRD) menunjukkan bahwa silika gel adalah amorf sedangkan hasil BET surface area analyzer menunjukkan bahwa silika gel termasuk dalam mesopori dengan volume total pori dan luas permukaan spesifik silika gel tertinggi diperoleh pada $\mathrm{pH} 9$ dan dengan konsentrasi PEG $60000,03 \mathrm{~g} / 100 \mathrm{~mL}$ yaitu masing-masing $124,574 \mathrm{~cm}^{3} / \mathrm{g}$ dan $285,456 \mathrm{~m}^{2} / \mathrm{g}$.

\section{Pendahuluan}

Silikon dioksida (silika) dapat berupa silika alami maupun sintetik, berbentuk kristal atau amorf [1]. Silika merupakan bahan kimia yang pemanfaatan dan aplikasinya sangat luas, mulai bidang elektronik, kimia, medis, hingga bidang-bidang lainnya. Silica gel termasuk silika sintetik yang tidak berbentuk kristal 
tetapi amorf [2]. Silica gel merupakan suatu bahan yang penggunaannya secara luas sebagai adsorben air (desiccant) karena kapasitas adsorpsi yang besar untuk air dan mudah untuk diregenerasi. Silica gel yang memiliki ukuran diameter pori $>20 \AA$ memiliki nilai ekonomi yang tinggi [2].

Penelitian tentang sintesis silica gel telah banyak dilakukan, baik dengan menggunakan sumber silika alami maupun sintetik telah mensintesis silica gel menggunakan $\mathrm{Na}_{2} \mathrm{SiO}_{3}$ dan $\mathrm{HNO}_{3}$ dengan metode solgel. Hasil yang diperoleh memiliki luas permukaan sebesar $155 \mathrm{~m}^{2} / \mathrm{g}$, diameter pori termasuk mikropori (< $20 \AA$ ) , dan volume pori $0,049 \mathrm{~cm}^{3} / \mathrm{g}$. Silica gel yang dibuat dari silikon alkoksida umumnya menggunakan tetrametilortosilikat (TMOS) atau tetraetilortosilikat (TEOS) sebagai sumber silika [3]. Keuntungan sintesis silica gel dari bahan baku TEOS adalah tidak terbentuk pengotor seperti garam sebagai hasil samping sehingga tidak memerlukan pencucian yang lama.

Boonamnuayvitaya $d k k$. [4] telah melakukan sintesis dan karakterisasi silica gel dari tetraethoxysilane (TEOS), etanol, akuades, dan etanol dengan metode solgel menggunakan surfaktan cetyltrimethyl ammonium bromide (CTABr), sodium dodecyl sulfate (SDS), dan polyoxyethylene cetyl ether sebagai pencetak pori. Silica gel yang diperoleh dengan menggunakan surfaktan cetyltrimethyl ammonium bromide (CTABr) ukuran diameter pori $26,3 \AA$, volume pori $0,723 \mathrm{~cm}^{3} / \mathrm{g}$, dan luas permukaan yang tinggi $1282 \mathrm{~m}^{2} / \mathrm{g}$.

Venkatathri [5] melakukan riset tentang sintesis silica gel nanosphere pada sistem homogen yaitu larutan dapat bercampur dengan baik antara TEOS dengan air dan sistem heterogen yaitu larutan tidak dapat bercampur dengan baik antara TEOS dengan air. Sistem heterogen terdiri dari TEOS dan air tanpa adanya penambahan etanol sedangkan sistem homogen terdiri dari TEOS dan air serta adanya etanol. Sintesis dilakukan dengan menggunakan TEOS sebagai sumber silika, larutan ammonia (katalis basa), akuades, etanol dan cetyltrimethyl ammonium bromide (CTABr) sebagai surfaktan. Kondisi sistem homogen tanpa penambahan $\mathrm{CTABr}$ dihasilkan ukuran partikel 100 dan 300 nanometer dengan rendemen rendah $(77 \%)$. Kondisi sistem homogen dengan penambahan CTABr dihasilkan ukuran partikel 100-500 nanometer, dan rendemen tinggi $(100 \%)$ sedangkan pada kondisi sistem heterogen dengan penambahan CTABr dihasilkan ukuran partikel 200 nanometer dan rendemen sebesar $94 \%$ serta luas permukaan silica gel $>1000 \mathrm{~m}^{2} / \mathrm{g}$.

Vong dkk. [6] telah mensintesis silica gel menggunakan TEOS, air, etanol, $\mathrm{NH}_{4} \mathrm{OH}$ serta Polyethylene Glycol (PEG). Penelitian dilakukan dengan ratio molar TEOS: $\mathrm{H}_{2} \mathrm{O}: \mathrm{C}_{2} \mathrm{H}_{5} \mathrm{OH}: \mathrm{NH}_{4} \mathrm{OH}$ yaitu 1: 4: 37: 0,001 . Polyethylene Glycol (PEG) yang digunakan yaitu PEG 200, PEG 400, PEG 600, dan PEG 1000. Polyethylene Glycol ditambahkan dengan berbagai variasi konsentrasi yaitu $1-10 \%$.

\section{Metode Penelitian}

\section{Alat \& Bahan}

Peralatan yang digunakan dalam penelitian ini adalah alat pemanasan (oven ARISTON type F-16-EMIN-02, furnace), peralatan gelas, neraca analitis, perlengkapan stirrer, krus porselain, spektrofotometer infra merah (FTIR merk SHIMADZU) dan BET (Braunaneur-Emmet-Teller) surface area analyzer.

Bahan-bahan yang digunakan dalam penelitian ini meliputi tetraetilortosilikat (TEOS) p.a. (Merck), polietilen glikol 6000 p.a. (Merck), amonium hidroksida p.a. (Merck), etanol p.a. (Merck), dan akuades.

\section{Sintesis Silica Gel Tanpa Penambahan $\mathrm{NH}_{4} \mathrm{OH}$}

Sebanyak $20 \mathrm{~mL}$ larutan tetraetilortosilikat (TEOS) p.a. ditambah $25 \mathrm{~mL}$ etanol p.a. diaduk dengan menggunakan stirrer. Setelah itu, ke dalam larutan ditambahkan 6,4 mL akuades kemudian larutan diaduk hingga homogen. Selanjutnya larutan didiamkan pada temperatur kamar sehingga diperoleh gel padat transparan. Gel padat transparan dipanaskan dalam oven pada suhu $80^{\circ} \mathrm{C}$ selama 18 jam untuk proses aging. Selanjutnya silica gel dicuci dengan akuades hingga $\mathrm{pH}$ netral dan dipanaskan kembali pada suhu $100^{\circ} \mathrm{C}$ selama 2 jam kemudian dihaluskan.

\section{Sintesis Silica Gel dengan Penambahan $\mathrm{NH}_{4} \mathrm{OH}$}

Sebanyak $20 \mathrm{~mL}$ larutan tetraetilortosilikat (TEOS) p.a. ditambah $25 \mathrm{~mL}$ etanol p.a. diaduk dengan menggunakan stirrer, kemudian ke dalam larutan ditambahkan 6,4 mL akuades. Larutan ditambah $\mathrm{NH}_{4} \mathrm{OH}$ hingga $\mathrm{pH}$ 8. Perlakuan sama untuk sintesis Silica Gel pH 9 dan 10. Larutan diaduk hingga homogen. Selanjutnya larutan didiamkan pada temperatur kamar sehingga diperoleh gel padat transparan. Gel padat transparan dipanaskan dalam oven pada suhu $80^{\circ} \mathrm{C}$ selama $18 \mathrm{jam}$ untuk proses aging. Silica gel dicuci dengan akuades hingga $\mathrm{pH}$ netral. Setelah itu dipanaskan kembali pada suhu $100^{\circ} \mathrm{C}$ selama 2 jam kemudian dihaluskan.

\section{Sintesis Silica Gel dari Tetraetilortosilikat (TEOS) dengan Adanya Penambahan Surfaktan Polietilen Glikol (PEG) 6000}

Sebanyak $20 \mathrm{~mL}$ larutan tetraetil ortosilikat (TEOS) p.a. dalam gelas beker ditambah $25 \mathrm{~mL}$ etanol p.a diaduk dengan menggunakan stirrer, kemudian ke dalam larutan ditambahkan $6,4 \mathrm{~mL}$ akuades. Selanjutnya dilakukan penambahan larutan polietilen glikol 6000 p.a. dengan variasi konsentrasi $0,01 \mathrm{~g} / 100 \mathrm{~mL} ; 0,03$ $\mathrm{g} / 100 \mathrm{~mL} ; 0,06 \mathrm{~g} / 100 \mathrm{~mL}$ pada $\mathrm{pH}$ gelasi tercepat, kemudian diaduk hingga homogen. Larutan didiamkan pada temperatur kamar sehingga diperoleh gel padat transparan. Gel padat transparan dibilas dengan akuades kemudian dipanaskan dalam oven pada suhu $80^{\circ} \mathrm{C}$ selama 18 jam untuk proses aging. Silica gel dicuci dengan akuades hingga $\mathrm{pH}$ netral dan dipanaskan kembali pada suhu $100^{\circ} \mathrm{C}$ selama 2 jam. Silica gel yang diperoleh dipanaskan kembali dengan furnace pada suhu $600^{\circ} \mathrm{C}$ selama 2 jam. Silica gel kering yang dihasilkan kemudian dikarakterisasi. 


\section{Hasil Dan Pembahasan}

Penentuan pH Gelasi Tercepat pada Sintesis Silica Gel dari Tetraetilortosilikat (TEOS)

Sintesis silica gel dilakukan dengan metode sol-gel dan menggunakan prekursor tetraetilortosilikat (TEOS). Sintesis silica gel dilakukan dengan menghidrolisis tetraetilortosilikat dalam pelarut etanol dengan menggunakan air dan menggunakan katalis amonium hidroksida. Penggunaan etanol berfungsi sebagai pelarut agar TEOS dapat bercampur dengan baik dengan air sehingga reaksi hidrolisis dapat berlangsung. Reaksi yang terjadi dalam sintesis silica gel antara lain reaksi hidrolisis dan reaksi kondensasi. Reaksi hidrolisis terjadi saat TEOS dan air bercampur dalam etanol. Reaksi kimianya yaitu:

$$
\mathrm{Si}\left(\mathrm{OC}_{2} \mathrm{H}_{5}\right)_{4}+\mathrm{xH}_{2} \mathrm{O} \rightleftharpoons \mathrm{Si}\left(\mathrm{OC}_{2} \mathrm{H}_{5}\right)_{4-\mathrm{x}}(\mathrm{OH})_{\mathrm{x}}+\mathrm{xC}_{2} \mathrm{H}_{5} \mathrm{OH}
$$

Adanya katalis $\mathrm{NH}_{4} \mathrm{OH}$ mempercepat laju reaksi dalam sintesis silica gel. Menurut Khimich [7], adanya katalis basa akan mempercepat laju reaksi. Reaksi hidrolisis pada kondisi basa yaitu:

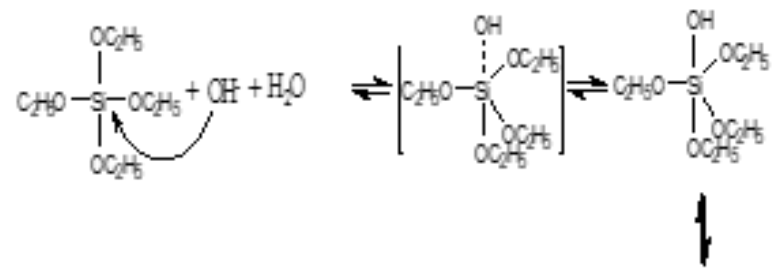

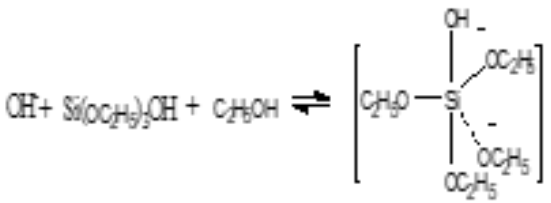

Selanjutnya akan terjadi reaksi kondensasi setelah terbentuk silanol.

Reaksi kondensasi yang terjadi dalam sintesis ini yaitu kondensasi dengan melepas air dan kondensasi dengan melepas alkohol [8]. Reaksi tersebut yaitu:

Kondensasi dengan melepas air

$$
\mathrm{Si}(\mathrm{OH})_{4}+(\mathrm{HO})_{4} \mathrm{Si} \stackrel{\mathrm{NH}_{4} \mathrm{OH}}{\longrightarrow}(\mathrm{HO})_{3} \mathrm{Si}-\mathrm{O}-\mathrm{Si}(\mathrm{OH})_{3}+\mathrm{H}_{2} \mathrm{O}
$$

Kondensasi dengan melepas alkohol

$$
\mathrm{Si}\left(\mathrm{OC}_{2} \mathrm{H}_{5}\right)_{4}+(\mathrm{HO})_{4} \mathrm{Si} \underset{\mathrm{C}_{2} \mathrm{H}_{5} \mathrm{OH}}{\stackrel{\mathrm{NH}_{4} \mathrm{OH}}{\longrightarrow}}(\mathrm{HO})_{3} \mathrm{Si}-\mathrm{O}-\mathrm{Si}\left(\mathrm{OC}_{2} \mathrm{H}_{5}\right)_{3}+
$$

Setelah terbentuk silanol maka antara silanol yang satu dengan yang lain membentuk polimer atau terjadi reaksi polikondensasi. Partikel-partikel sol mulai terbentuk dengan terbentuknya beberapa ikatan Si-OSi, kemudian sol tersebut beragregasi dan membentuk jaringan yang kemudian membentuk gel. Gel yang terbentuk dibiarkan beberapa waktu hingga terbentuk gel padat. Gel padat tersebut kemudian dilakukan pemanasan pada suhu $80^{\circ} \mathrm{C}$ selama 18 jam. Pemanasan tersebut bertujuan untuk menghilangkan etanol hasil samping dari sintesis gel silika. Selain itu, proses ini juga disebut aging. Pemanasan pada suhu $100^{\circ} \mathrm{C}$ selama 2 jam bertujuan untuk menghilangkan air pada sintesis silica gel. Berdasarkan hasil penelitian, kondisi $\mathrm{pH} 9$ merupakan kondisi tercepat untuk permbentukan gel. Data hasil penelitian dapat dilihat pada gambar 1.

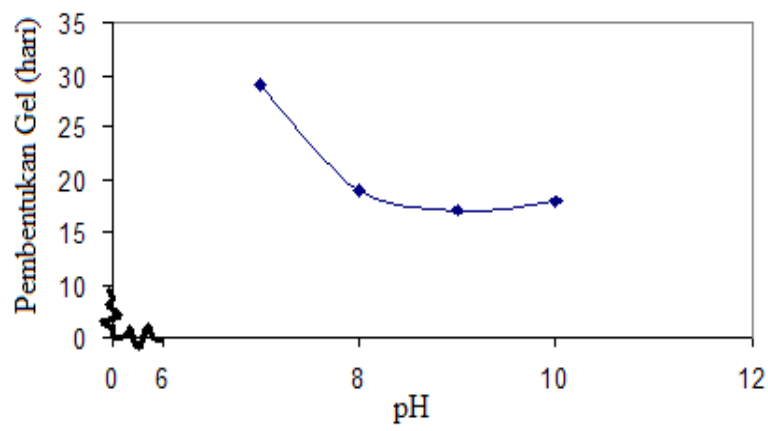

Gambar 1. Pengaruh pH terhadap waktu pembentukan gel

Berdasarkan hasil penelitian diketahui bahwa penambahan larutans amonia mempercepat pembentukan gel pada silica gel. Sintesis silica gel pada kondisi pH 9 pembentukan gel (17 hari) tercepat karena semakin tinggi konsentrasi $\mathrm{OH}^{-}$maka akan semakin cepat pembentukan ikatan $\mathrm{Si}-\mathrm{O}-\mathrm{Si}$ sehingga gelasi semakin cepat. Sintesis silica gel pada kondisi $\mathrm{pH} 10$ (waktu pembentukan gel 19 hari) dimungkinkan terjadi kelebihan gugus $\mathrm{OH}^{-}$yang dapat mengganggu pembentukan $\mathrm{Si}-\mathrm{O}-\mathrm{Si}$ sehingga proses gelasi lebih lambat.

\section{Sintesis Silica Gel dengan Penambahan Surfaktan Polietilen Glikol (PEG) 6000}

Sintesis Silica gel menggunakan penambahan PEG 6000 dilakukan untuk mendapatkan porositas yang lebih tinggi. Sintesis dilakukan pada kondisi $\mathrm{pH} 9$ dengan variasi konsentrasi PEG 6000 yaitu $0,01 \mathrm{~g} / 100$ $\mathrm{mL} ; 0,03 \mathrm{~g} / 100 \mathrm{~mL} ; 0,06 \mathrm{~g} / 100 \mathrm{~mL}$. Pemanasan tehadap hasil sintesis silica gel pada suhu $600^{\circ} \mathrm{C}$ bertujuan untuk menghilangkan PEG 6000 sehingga tempat yang ditinggalkan akan terbentuk pori sehingga diharapkan porositasnya tinggi.

\section{Karakterisasi dengan Spektro-fotometer IR}

Karakterisasi terhadap silica gel hasil sintesis dilakukan dengan spektrofotometer IR untuk memprediksi gugus-gugus yang ada dalam silica gel tersebut. Pita-pita serapan yang diukur pada daerah bilangan gelombang antara $300-4000 \mathrm{~cm}^{-1}$ yaitu pada daerah bilangan gelombang yang mengandung gugusgugus penyusun silica gel. Spektra FTIR silica gel hasil sintesis memiliki kemiripan pola setelah dibandingkan dengan silica gel standar. Spektra FTIR silica gel hasil sintesis disajikan pada gambar 2, 3, dan 4.

Hasil FTIR silica gel tanpa penambahan $\mathrm{NH}_{4} \mathrm{OH}$ dan silica gel dengan penambahan $\mathrm{NH}_{4} \mathrm{OH}$ yaitu $\mathrm{SG} 1$ dan $\mathrm{SG} 2$ 


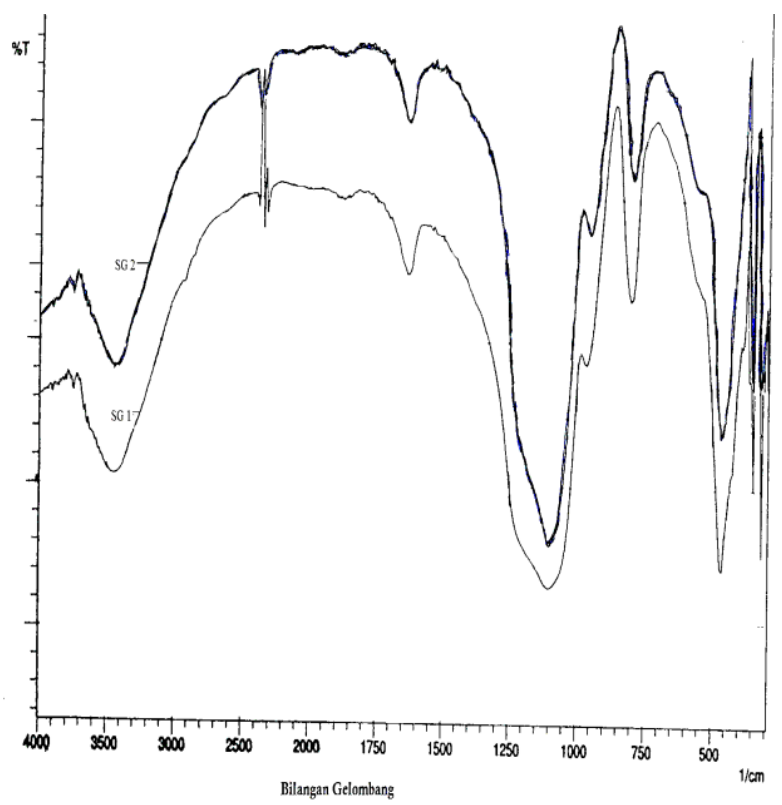

Gambar 2. Spektra FTIR SG 1 dan SG 2

Keterangan:

SG 1: Silica Gel pH 7 (tanpa penambahan $\mathrm{NH}_{4} \mathrm{OH}$ )

SG 2: Silica Gel pH 9

Interpretasi spektra inframerah silica gel tersebut disajikan dalam tabel 1.

Tabel 1: Daftar bilangan gelombang pada silica gel hasil sintesis

\begin{tabular}{|c|c|c|}
\hline \multirow{2}{*}{ Interpretasi } & \multicolumn{2}{|c|}{$\begin{array}{c}\text { Bilangan } \\
\text { Gelombang }\left(\mathrm{cm}^{-1}\right)\end{array}$} \\
\hline & SG 1 & SG 2 \\
\hline Vibrasi ulur $-\mathrm{OH}$ pada $\mathrm{Si}-\mathrm{OH}$ & 3749,62 & 3749,62 \\
\hline Vibrasi ulur $-\mathrm{OH}$ pada $\mathrm{Si}-\mathrm{OH}$ & 3448,72 & 3448,72 \\
\hline Vibrasi tekuk -OH pada $\mathrm{Si}-\mathrm{OH}$ & 1635,64 & 1627,92 \\
\hline $\begin{array}{l}\text { Vibrasi ulur asimetri } \mathrm{Si}-\mathrm{O} \\
\text { pada } \mathrm{Si}-\mathrm{O}-\mathrm{Si}\end{array}$ & 1103,28 & 1103,28 \\
\hline Vibrasi tekuk $\mathrm{Si}-\mathrm{O}$ pada $\mathrm{Si}-\mathrm{OH}$ & 964,41 & 956,69 \\
\hline $\begin{array}{l}\text { Vibrasi ulur simetri Si-O pada } \\
\qquad \mathrm{Si}-\mathrm{O}-\mathrm{Si}\end{array}$ & 802,39 & 802,39 \\
\hline $\begin{array}{l}\text { Vibrasi tekuk Si-O pada } \mathrm{Si}-\mathrm{O}- \\
\mathrm{Si}\end{array}$ & 462,92 & 462,92 \\
\hline
\end{tabular}

Gambar spektra FTIR di atas terlihat bahwa silica gel hasil sintesis SG 1 dan SG 2 mempunyai kemiripan pola. Spektra yang muncul pada bilangan gelombang sekitar $3400 \mathrm{~cm}^{-1}$ hingga sekitar $3900 \mathrm{~cm}^{-1}$ yang merupakan vibrasi gugus $-\mathrm{OH}$ (gugus hidroksil) dari $\mathrm{Si}-\mathrm{OH}$. Vibrasi gugus $-\mathrm{OH}$ dari $\mathrm{Si}-\mathrm{OH}$ juga muncul pada bilangan gelombang sekitar $1600 \mathrm{~cm}^{-1}$. Spektra pada bilangan gelombang sekitar $950 \mathrm{~cm}^{-1}$ merupakan vibrasi gugus $\mathrm{Si}-\mathrm{O}$ dari $\mathrm{Si}-\mathrm{OH}$ dan sekitar $1103 \mathrm{~cm}^{-1}$ merupakan vibrasi gugus Si-O dari Si-O-Si. Puncak spektra pada bilangan gelombang sekitar 462 dan sekitar $800 \mathrm{~cm}^{-1}$ merupakan vibrasi gugus $\mathrm{Si}-\mathrm{O}$ dari $\mathrm{Si}-\mathrm{O}-\mathrm{Si}$. Penggunaan $\mathrm{NH}_{4} \mathrm{OH}$ pada sintesis silica gel ini berfungsi sebagai katalis yang mempercepat pembentukan gel, tidak berpengaruh terhadap pola spektra yang dihasilkan.
Hasil FTIR silica gel tanpa penambahan PEG 6000 dan silica gel dengan penambahan PEG 6000 yaitu SG 2, SG 2A, dan SG 2C

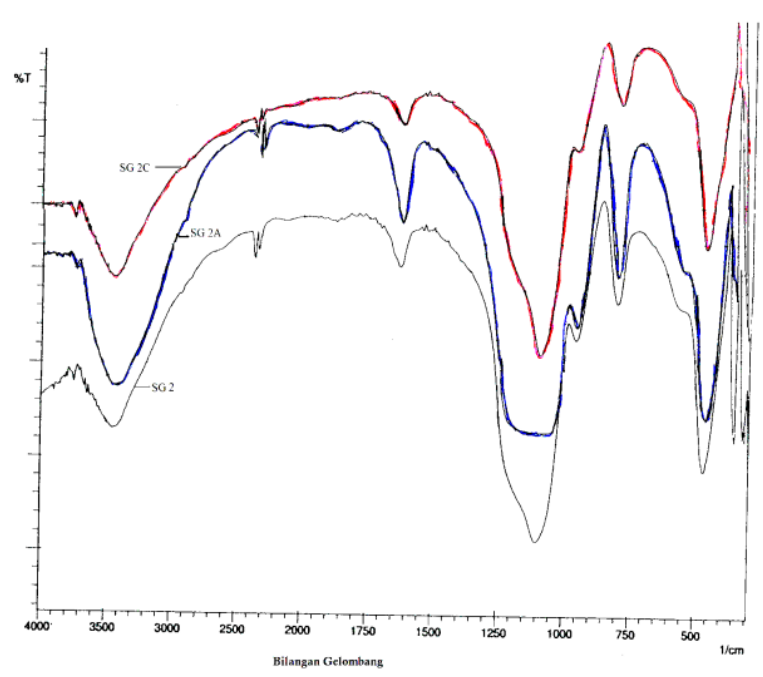

Gambar 3. Spektra FTIR SG 2, SG 2A, dan SG 2C

Keterangan:

SG 2 : Silica Gel pH 9

SG 2A : Silica Gel pH 9 + PEG 6000 konsentrasi 0,01 $\mathrm{g} / 100 \mathrm{~mL}$

SG 2C : Silica Gel pH 9 + PEG 6000 konsentrasi 0,06 $\mathrm{g} / 100 \mathrm{~mL}$

Spektra SG 2, SG 2A, dan SG 2C mirip. Akan tetapi, ada sedikit perbedaan pita serapan yaitu pada SG $2 \mathrm{~A}$ yang muncul dua pita serapan untuk vibrasi $\mathrm{Si}-\mathrm{O}$ pada bilangan gelombang 1118,71 dan $1087,85 \mathrm{~cm}^{-1}$ yang menjadikan pita serapan pada daerah tersebut lebih melebar. Tidak adanya pita serapan yang karakteristik untuk surfaktan PEG 6000 pada spektra SG 2A dan SG 2C menandakan surfaktan tersebut telah hilang. Surfaktan PEG 6000 dimungkinkan telah larut pada saat pencucian dengan akuades karena PEG 6000 mudah larut dalam air (kelarutan PEG 6000 dalam air sebesar $500 \mathrm{~g} / \mathrm{L})$.

Hasil FTIR silica gel sebelum dan sesudah pemanasan $600^{\circ} \mathrm{C}$ yaitu SG 2A 1, SG 2A 2, SG 2C 1, dan SG 2C 2

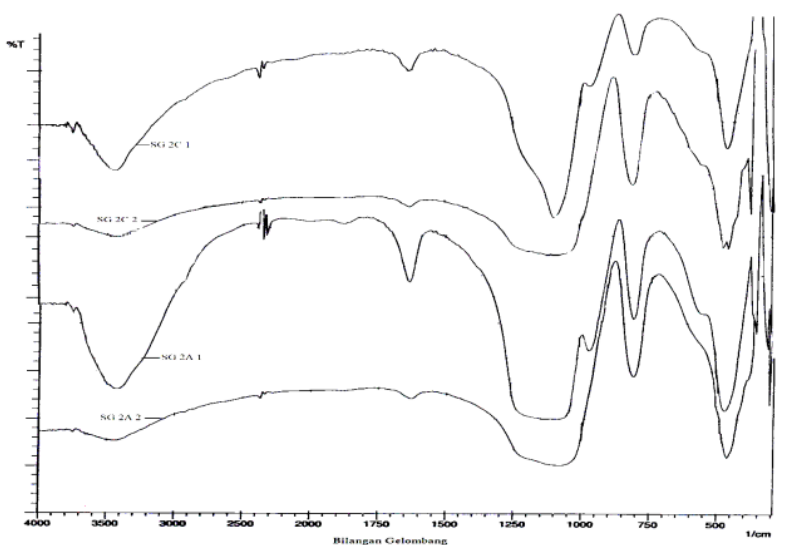

Gambar 4. Spektra FTIR SG 2A 1, SG 2A 2, SG 2C 1 dan SG $2 \mathrm{C} 2$ 
Keterangan:

SG 2A 1 : Silica Gel pH 9 + PEG 6000 konsentrasi 0,01 $\mathrm{g} / 100 \mathrm{~mL}$ sebelum pemanasan $600^{\circ} \mathrm{C}$

SG 2A 2 : Silica Gel pH 9 + PEG 6000 konsentrasi 0,01 $\mathrm{g} / 100 \mathrm{~mL}$ setelah pemanasan $600^{\circ} \mathrm{C}$

SG 2C 1 : Silica Gel pH 9 + PEG 6000 konsentrasi 0,06 $\mathrm{g} / 100 \mathrm{~mL}$ sebelum pemanasan $600^{\circ} \mathrm{C}$

SG 2C 2 : Silica Gel pH 9 + PEG 6000 konsentrasi 0,06 $\mathrm{g} / 100 \mathrm{~mL}$ setelah pemanasan $600^{\circ} \mathrm{C}$

Spektra pada SG 2A 1, SG 2A 2, SG 2C 1, dan SG 2C 2 terlihat perbedaan yaitu spektra pada bilangan gelombang sekitar 900, 1627, 3400 hingga $3749 \mathrm{~cm}^{-1}$ sangat lemah atau hampir tidak muncul puncak serapan gugus untuk $-\mathrm{OH}$ dari $\mathrm{Si}-\mathrm{OH}$. Hal ini menunjukkan bahwa gugus tersebut diperkirakan banyak yang hilang karena mengalami dehidrasi akibat dipanaskan pada suhu $600^{\circ} \mathrm{C}$. Selain itu, dengan adanya pemanasan merusak struktur dari silica gel pada daerah sekitar 1100 $\mathrm{cm}^{-1}$ yang merupakan daerah vibrasi $\mathrm{Si}-\mathrm{O}$.

\section{Karakterisasi dengan Difraksi Sinar-X (XRD)}

Untuk mengetahui kristalinitas silica gel hasil sintesis dilakukan analisis menggunakan difraksi sinar$\mathrm{X}$ (XRD). Silica gel hasil sintesis pada $\mathrm{pH} 9$ yang merupakan kondisi $\mathrm{pH}$ optimum pembentukan gel tercepat dianalisis menggunakan difraksi sinar-X (XRD). Hasil analisis tersebut dapat dilihat pada gambar 5 .

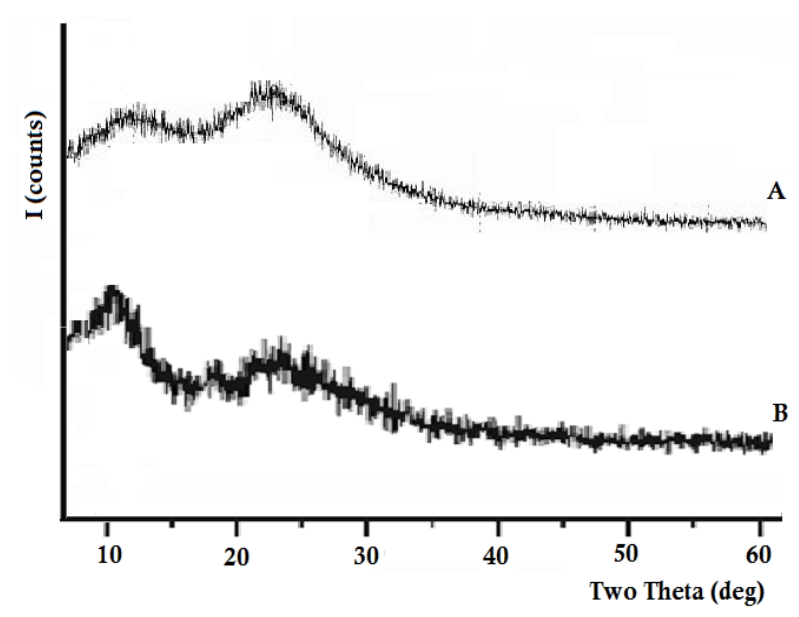

Gambar 5. Difraktogram XRD SG 2 (A), silica gel hasil sintesis (B)

Berdasarkan pola difraktogram XRD hasil pengukuran di atas menunjukkan bahwa tidak terdapat puncak-puncak tajam yang mengindikasikan suatu kristalin dari silica gel hasil sintesis. Pola difraktogram XRD silica gel hasil sintesis memiliki pola yang sama dengan difraktrogram XRD silica gel Vijayalakshmi $d k k$. [3] yang menunjukkan bahwa sampel silica gel bersifat amorf.

\section{Karakterisasi dengan BET surface area analyzer}

Karakterisasi dengan menggunakan BrunauerEmmet-Teller (BET) surface area analyzer memberikan informasi mengenai ukuran diameter pori, luas permukaan spesifik dan volume total pori dari suatu material berpori.
Tabel 2: Data hasil BET yang meliputi: luas permukan spesifik, total volume pori, dan rata-rata radius pori pada berbagai jenis silica gel sintesis

\begin{tabular}{cccc}
\hline Sampel & $\begin{array}{c}\text { Luas } \\
\text { Permukaan } \\
\text { Spesifik } \\
\left(\mathrm{m}^{2} / \mathrm{g}\right)\end{array}$ & $\begin{array}{c}\text { Volume } \\
\text { Total } \\
\text { Pori } \\
\left(\mathrm{cm}^{3} / \mathrm{g}\right)\end{array}$ & $\begin{array}{c}\text { Rata-rata } \\
\text { Diameter } \\
\text { Pori }(\AA)\end{array}$ \\
\hline SG 2 & 150,147 & 65,703 & 27,036 \\
SG 2A & 278,237 & 121,723 & 27,030 \\
SG 2B & 285,459 & 124,574 & 26,964 \\
SG 2C & 282,980 & 122,818 & 26,816 \\
\hline
\end{tabular}

Keterangan:

SG 2 : Silica Gel pH 9

SG 2A : Silica Gel pH 9 + PEG 6000 konsentrasi 0,01 $\mathrm{g} / 100 \mathrm{~mL}$

SG 2B : Silica Gel pH 9 + PEG 6000 konsentrasi 0,03 $\mathrm{g} / 100 \mathrm{~mL}$

SG 2C : Silica Gel pH 9 + PEG 6000 konsentrasi 0,06 $\mathrm{g} / 100 \mathrm{~mL}$

Tabel 2 menunjukan bahwa silica gel hasil sintesis baik tanpa menggunakan maupun menggunakan penambahan PEG 6000 menghasilkan rata-rata diameter pori pada daerah mesopori (>20 $\AA$ ) dengan nilai diameter masih dalam batas bawah kategori mesopori (20-500 $\AA$ ) [9]. Hasil karakterisasi sintesis silica gel tersebut menunjukkan bahwa luas permukaan spesifik dan volume total pori silica gel semakin tinggi dengan penambahan surfaktan PEG 6000. Adanya surfaktan PEG 6000 dimungkinkan partikel silika berada di sepanjang molekul PEG 6000 sehingga luas permukaan silica gel yang terbentuk lebih luas. Luas Permukaan yang besar dengan volume total pori yang besar menunjukkan bahwa jumlah pori pada silica gel banyak. Berdasarkan data yang diperoleh dari hasil analisis menggunakan BET surface area analyzer dapat dijelaskan kemungkinan mekanisme interaksi silika dengan surfaktan PEG 6000 yaitu:

Mekanisme surfaktan membentuk cincin dan mencetak pori-pori silica gel

Surfaktan membentuk cincin yang sangat besar dengan kedua pangkal ujung saling bertemu,sedangkan prtikel silika berada mengelilingi cincin PEG 6000 dan membentuk pori mengikuti bentuk cincin PEG 6000 . Pembentukan cincin oleh molekul surfaktan terjadi apabila kedua ujung surfakan PEG 6000 bertemu. Akan tetapi, karena bobot molekul surfaktan PEG 6000 sangat besar $(\mathrm{BM}=6000)$ dengan nilai derajat polimerisasi mencapai sekitar 97 yang berarti rantai karbon PEG 6000 sangat panjang, sehingga antar ujung surfaktan sulit bertemu membentuk cincin. Oleh karena itu, mekanisme ini kemungkinan tidak terjadi dan template jenis ini tidak terbentuk.

\section{Mekanisme surfaktan PEG 6000 membentuk misel}

Mekanisme ini, surfaktan PEG 6000 membentuk misel yang stabil kemudian partikel silika mengelilingi misel. Mekanisme ini sangat sulit terjadi karena molekul surfaktan memiliki rantai karbon yang sangat panjang sehingga sulit untuk membentuk struktur misel yang 
stabil. Di samping itu, CMC dari PEG 6000 (sekitar 5 x10${ }^{4} \mathrm{M}$ ) tidak terlampaui sehingga tidak terbentuk misel.

\section{Mekanisme surfaktan PEG 6000 tetap utuh sebagai molekul yang memanjang}

Mekanisme ini, molekul surfaktan membentuk molekul yang berkelok-kelok karena rantai karbon PEG 6000 terlalu panjang dan antar ujung surfakan tidak bertemu. Partikel silika berada di sekeliling rantai surfakan. Mekanisme ini lebih sesuai untuk menjelaskan data hasil analisis menggunakan metode BET yang menunjukkan bahwa penambahan PEG 6000 dan berbagai variasi konsentrasinya tidak menghasilkan kenaikan diameter pori silica gel tetapi menghasilkan diameter pori yang cenderung sama.

\section{Kesimpulan}

Pembentukan gel tercepat sintesis silica gel dicapai pada kondisi pH 9 yaitu 17 hari. Sintesis silica gel dari tetraetilortosilikat menggunakan surfaktan Polyethylene Glycol (PEG) 6000 berhasil dilakukan. Silica gel hasil sintesis bersifat amorf dan diameter pori termasuk mesopori (> $20 \AA$ ). Penggunaan Polyethylene Glycol (PEG) 6000 tidak memberikan peningkatan radius pori tetapi meningkatkan luas permukaan spesifik dan volume total pori. Luas permukaan spesifik tertinggi dan volume total pori terjadi pada silica gel $\mathrm{pH}$ 9 dengan penambahan PEG 6000 kosentrasi 0,03 g/100 $\mathrm{mL}$ yaitu $285,459 \mathrm{~m} 2 / \mathrm{g}$ dan $124,574 \mathrm{~cm} 3 / \mathrm{g}$

\section{Daftar Pustaka}

[1] Horacio E Bergna, William O Roberts, Colloidal silica: fundamentals and applications, CRC Press, 2005.

[2] Ralph T Yang, Adsorbents: fundamentals and applications, John Wiley \& Sons, 2003.

[3] U Vijayalakshmi, A Balamurugan, S Rajeswari, Synthesis and characterization of porous silica gels for biomedical applications, Trends Biomaterials \& Artificial Organs, 18, 2, (2005) 101-105

[4] Virote Boonamnuayvitaya, Chadapa Tayamanon, Srisuda Sae-ung, Wiwut Tanthapanichakoon, Synthesis and characterization of porous media produced by a sol-gel method, Chemical Engineering Science, 61, 5, (2006) 1686-1691 http://dx.doi.org/10.1016/j.ces.2005.10.002

[5] N Venkatathri, Synthesis of silica nanosphere from homogeneous and heterogeneous systems, Bulletin of Materials Science, 30, 6, (2007) 615-617 http://dx.doi.org/10.1007/s12034-007-0097-3

[6] M.S.W. Vong, N. Bazin, P.A. Sermon, Chemical Modification of Silica Gels, Journal of Sol-Gel Science and Technology, 8, 1, (1997) 499-505 http://dx.doi.org/10.1023/a:1018350227105

[7] N. N. Khimich, Synthesis of Silica Gels and OrganicInorganic Hybrids on Their Base, Glass Physics and Chemistry, 30, 5, (2004) 430-442 http://dx.doi.org/10.1023/B:GPAC.0000045925.8413 9.eb

[8] A. Venkateswara Rao, Sharad D. Bhagat, Synthesis and physical properties of TEOS-based silica aerogels prepared by two step (acid-base) sol-gel process, Solid State Sciences, 6, 9, (2004) 945-952 http://dx.doi.org/10.1016/j.solidstatesciences.2004. 04.010

[9] Etienne F Vansant, Pascal Van Der Voort, Karl C Vrancken, Preface, in, Elsevier, 1995. 